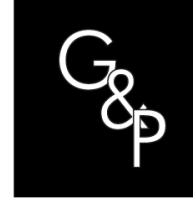

\title{
Dynamic method to identify and analyze waste by making-do in construction sites
}

\section{Método dinâmico para identificar e analisar perdas por making-do em canteiros de obras}

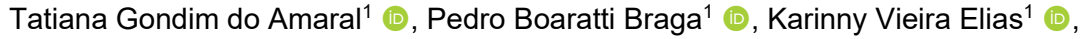 \\ Camila Mariana Brandão ${ }^{1}$ (D) \\ ${ }^{1}$ Universidade Federal de Goiás - UFG, Department of Environmental and Civil Engineering, Goiânia, GO, Brasil. \\ E-mail: tatianagondim@ufg.br; pedrobraga.engcivil@gmail.com; karinnyelias22@gmail.com; c.mariana.b@gmail.com
}

How to cite: Amaral, T. G., Braga, P. B, Elias, K. V., \& Brandão, C. M. (2021). Dynamic method to identify and analyze wastes by making-do in construction sites. Gestão \& Produção, 28(3), e5676. https://doi.org/10.1590/1806-9649-2021v28e5676

\begin{abstract}
The study of making-do contributes to improvements in the planning and control of construction sites, thus minimizing waste. The present study aims to investigate and analyze waste by making-do in seven companies from Goiás with the aid of a Dashboard and perform the risk analysis of the identified waste. Data were analyzed during the technical visits at each site, among which the direct non-participant observation, questionnaire application and document analysis stand out. The analysis of the data indicated that most of the waste is related to the steps of sealing and structure within the construction sites, in particular, for components connected to plastering and concreting. The main impact was rework, followed by reduced security. With the risk analysis, the main points were identified according to their severity, thus guiding management decision making. As final contributions, the main impacts and suggestions for their minimization are presented. Therefore, we highlight the need to use reality and information technology tools in future works for integrated production control and to assist in the identification of waste by makingdo in construction sites.
\end{abstract}

Keywords: Waste; Making-do; Rework; Improvisation; Dashboard.

Resumo: O estudo de making-do contribui para melhorias no planejamento e controle de obras e consequentemente minimização das perdas. O presente trabalho tem como objetivo propor um método dinâmico para identificar e analisar as perdas por making-do em canteiros de obras. Foram analisados dados durante as visitas técnicas em cada obra, provenientes da observação direta não participante, aplicação de questionário e análise documental. A análise dos dados indicou que a maioria das perdas estão relacionadas às etapas de vedação e estrutura dentro dos canteiros, e em especial, para os componentes ligados ao reboco e aos serviços de concretagem. $O$ impacto principal ligado às perdas por making-do foi o retrabalho, seguido pela redução da segurança. Com a análise de risco, identificou-se os principais pontos de acordo com sua gravidade, orientando assim a tomada de decisão pela gerência. Como contribuições finais são apresentados os principais impactos e sugestões para a sua minimização. Sendo assim, destaca-se a necessidade de se utilizar em trabalhos futuros a realidade aumentada e as ferramentas de tecnologia da informação, para o controle integrado da produção e que auxiliem na identificação de perdas por making-do nos canteiros de obras.

Palavras-chave: Perdas; Making-do; Retrabalho; Improvisação; Planilhas Dinâmicas.

Received: Aug. 29, 2019 - Accepted: Jan. 17, 2020

Financial support: This work did not have any specific funding from institutions or agencies in the public, private or non-profit sectors. 


\section{Introduction}

Making the civil construction sector more competitive is a common goal among the academic and technical communities. Therefore, it is necessary to increase control and performance, reduce wastes and reduce impacts on the environment (Adewuyi et al. 2014; Ansah et al., 2016).

Thus, companies have to develop actions that provide improvements in construction processes, in order to avoid failures, wastes, accidents and rework, as to guarantee a high organizational level, reducing costs, meeting deadlines, minimizing errors, and improving quality and productivity.

Studies carried out in different countries indicate that wastes in civil construction represent a relatively high percentage of production costs (Formoso, 1998; Formoso et al., 2002; Formoso et al. 2017; Hwang et al., 2009; Koushki \& Kartam, 2004; Love \& Li, 2000; Leão et al., 2016).

In the civil construction sector, high production costs are related to wastes over the construction processes and should be understood as any inefficiency in the use of equipment, materials, labor and capital (Formoso et al., 1997; Viana et al., 2012).

Ohno (1988) proposed that waste or loss refers to all production resources that only increase costs and do not add value to the product, being identified in seven major categories of wastes in the manufacturing process: handling, waiting, overproduction, transportation, in processing itself, for running defective products, stock. It is important to highlight that loss and waste do not have the same meaning in construction management, being the first a broader term and the second related to material loss.

In this context, several theories emerged or underwent evolution, but for lean construction, the ninth category of wastes called making-do proposed by Koskela (2004), was undoubtedly an important contribution, added to the list widely known and applied by Ohno (1988) and Shingo (1989) and Formoso et al. (1997).

It is observed that the terms unfinished work, work in progress, buffer, rework, work termination, work interruption, have been re-conceptualized, in the sense of becoming associated with making-do. However, it is important to note that these terms already existed before the evolution of lean construction theory. As well, Ronen (1992) and Koskela $(1992,1999,2000)$ already brought in their work the theoretical bases for the making-do, with emphasis on the concept of complete kit as the definition of prerequirements to perform a given task.

Koskela (2004) defines the making-do as being a type of loss that occurs when the task is started or continued without all resources being available in its standard or optimal form.

The loss through making-do has been identified as the root cause of other wastes in production, such as accidents, quality problems, rework and overwork in progress (Fireman et al., 2013; Formoso et al., 2011 ; Leão et al., 2016).

Although the number of studies that measured wastes by making-do is still small, there are indications that these wastes are frequent in construction sites (Bonesi, 2014; Fireman, 2012; Silva, 2013; Sommer, 2010; Veloso, 2014).

Authors such as Ballard (2000), Formoso \& Moura (2009), Machado (2003), Santos (2004) pointed out that one of the most important causes of planning failures is the ineffective management of upstream flows (for example, supply of materials, design, equipment, among others).

In Brazil, the loss proposed by Koskela (2004) has been raised in several construction sites. Sommer (2010) relates the theme to improvisation within construction sites and lists preconditions, categories and impacts arising from it. Leão (2014) and Santos \& Santos, 
(2017) analyze the loss by making-do relating it to the integrated control of production and quality in the construction sites, and to unfinished work and cycle time, respectively.

It is possible to identify similarities between the categories of activities proposed by Machado (2003) and Santos (2004) and the categories of wastes due to improvisations presented by Sommer (2010). The difference is basically in the purpose. While Machado (2003) and Santos (2004) propose a list of actions that seek to avoid interruptions in production, Sommer (2010) presents the alternatives found by workers to prevent these interruptions from occurring (Leão et al., 2016).

It is from this theoretical framework that a systematic mapping of the literature was carried out to identify the knowledge gaps related to making-do, in order to contribute scientifically to the advances in the productive sector. There was then a knowledge gap regarding the dissemination of that knowledge in construction sites. Thus, the research question of the work was: what is the best method to analyze and categorize the occurrences of wastes due to making-do and its impacts?

To answer this question, specifically in Goiânia, the survey of wastes by making-do is part of a research group in which data were collected in seven construction companies in Goiás to identify the presence of wastes by making-do and its impacts (Brandão \& Elias, 2018; Dinoah et al., 2018; Braga, 2018).

The research group is expanding the sample to other states, such as Ceará, seeking to characterize the particularities of the data collected by country region and by constructive process. Due to the need to work with a larger sample and its difficulties in data analysis, the present work aims to propose a dynamic method to identify and analyze wastes due to making-do in construction sites.

\section{Method of identification and classification of wastes by making-do}

The elimination of wastes has been the main focus of companies that have adopted the management philosophy of lean construction (Sommer, 2010; Barbosa et al., 2013).

Soibelman (1993) warns that the reduction of wastes must consider that there is an acceptable level of wastes, which can only be reduced through significant changes in the level of technological and managerial development of the company.

Koskela (2000), presents the importance of knowing the prerequisites of the work to ensure its continuity, that is, he is concerned with avoiding improvisations, interruptions in the work and with increasing variability in the process. So, it relies on the concepts presented by Ronen (1992) of the Complete Kit and highlights the importance of starting the activity only when all the resources necessary for its execution are met.

Koskela (2000) defines these prerequisites as input flows, namely: information (design), materials and components, labor, machinery and equipment, prerequisite tasks, external conditions and space.

Koskela (2004) then proposes making-do as a new category added to the seven wastes proposed by Ohno (1988), defining the term as the loss that occurs when a task starts without all the necessary resources, or when it is continued, even with the absence of one or more resources. Thus, this loss can be identified by the occurrence of unfinished work (Fireman, 2012), which may be the result of interruptions at work (Santos \& Santos, 2017) or improvisations (Sommer, 2010), in order to perform an activity with what is available.

Evidence indicates that wastes from making-do are high at construction sites, since inefficient management of upstream flows (for example, supply of material, design, installation of workspace infrastructure, installation of equipment), makes the completion of the tasks defined in the short-term plans unfeasible (Formoso et al., 2011). 
Santos (2004) proposed an activity concept that, through the removal of restrictions or through managerial anticipation, brings improvements to a given process. These activities are improvement actions implemented in a specific sector to make processes more efficient and effective. According to the author, facilitating activities are those that contribute to avoid interruptions in the process. They relate to the concept of continuous improvement and provide a continuous flow of production that decreases the chances of loss due to making-do.

When investigating wastes from making-do, Fireman et al. (2013) identified their association with incomplete tasks and with the execution of informal work packages.

According to Alves (2000), terminality is understood to be the completion of tasks on time and with determined quality, without the need for the subsequent return of a team to carry out rework. When there is a lack of terminality in the tasks, their effective completion, in most cases, is not planned, resulting in informal tasks, subject to uncertainties and wastes due to making-do (Fireman et al., 2013).

According to Leão et al. (2016), the integration between production and quality controls is a means of reducing the incidence of informal packages and, consequently, wastes by making-do.

Ronen (1992), in turn, presents two domains of consequences for making-do: technical and behavioral. Regarding the technical consequences, according to Koskela (2004), Sommer (2010), Formoso et al. (2011), Fireman et al. (2013) making-do stands out for triggering increased variability and lead times, reduced safety, decreased quality, increased work in progress and increased rework. The behavioral consequences, according to Ronen (1992), are decreased motivation as well as less effort to ensure that all prerequisites are met.

Ohno (1997), highlights as a consequence of any type of loss, the increase in costs that do not add value to the final product. Formoso et al. (2011) and Fireman et al. (2013) state that the impact of making-do on the cycle time of processes is inevitable, since work is interrupted and new mobilization and demobilization operations are required, in addition to new processing, directly interfering with the planned schedule.

Based on the classification of incoming flows in the construction processes, Sommer (2010) proposed a method for identifying making-do in construction sites, this proposition took into consideration the assumptions of the authors Koskela (2004), Santos (2004), Ballard (2000) and Machado (2003) (Figure 1).

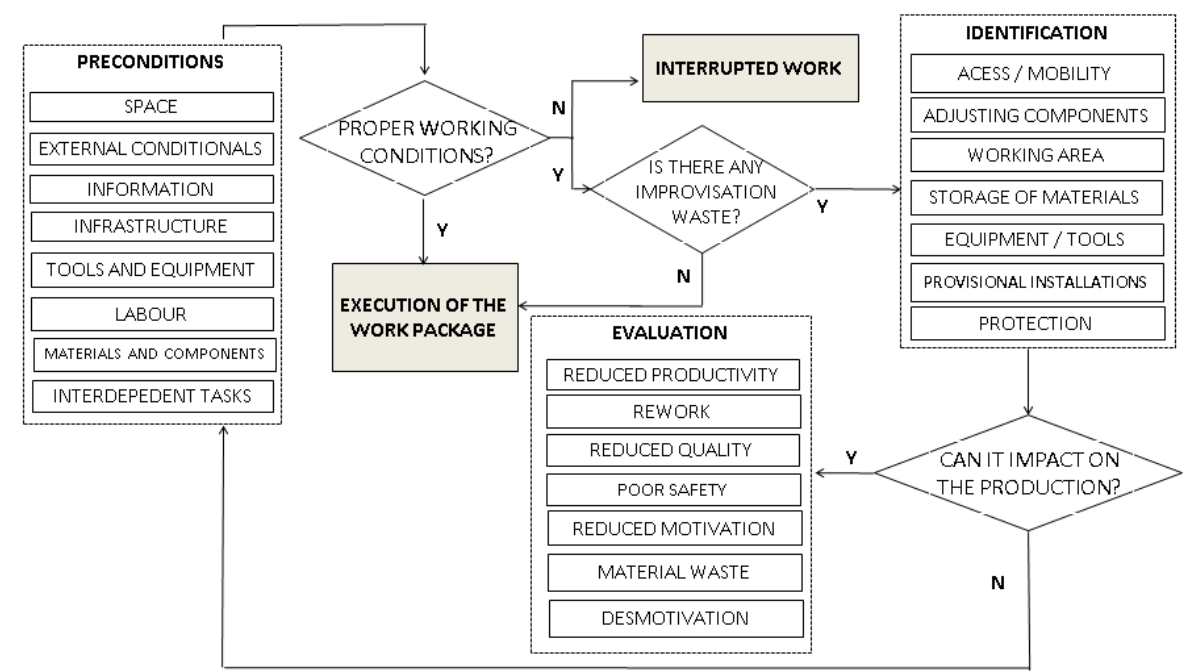

Figure 1. Classification of input flows in construction processes. Source: Sommer (2010) and Santos \& Santos (2017). 
Still in Figure 1, it can be seen that for the preconditions, Sommer (2010) used the seven flows / requirements proposed by Koskela (2000) and added to this list "workspace infrastructure", warning that, once not met, these Pre-conditions could cause making-do. From the framework that contributed to the theme, Sommer (2010) proposed the field Identification / category of wastes by making-do, with seven items, which was added to the category "sequencing" by Fireman (2012). Finally, in the Impact / evaluation field Fireman (2012) added "lack of terminality".

Table 1 presents a synthesis of these categories as well as the "Sequencing" category proposed by Fireman (2012) and applied by Leão (2014). The correspondences between the proposed categories, the missing preconditions for each category and impacts on production are also presented.

Table 1. Classification of wastes by making-do.

\begin{tabular}{|c|c|c|c|c|c|}
\hline $\begin{array}{l}\text { IDENTIFICATION / } \\
\text { CATEGORY }\end{array}$ & AUTHOR & $\begin{array}{c}\text { PRE } \\
\text { CONDITION }\end{array}$ & AUTHOR & $\begin{array}{c}\text { IMPACTI } \\
\text { EVALUATION }\end{array}$ & AUTHOR \\
\hline Access / mobility & \multirow{7}{*}{$\begin{array}{l}\text { Sommer } \\
(2010)\end{array}$} & Information & \multirow{7}{*}{$\begin{array}{l}\text { Sommer } \\
(2010) \\
\text { Koskela } \\
(2000)\end{array}$} & Low productivity & \multirow{6}{*}{$\begin{array}{l}\text { Sommer } \\
(2010)\end{array}$} \\
\hline Component adjustment & & $\begin{array}{l}\text { Materials and } \\
\text { components }\end{array}$ & & Decreased quality & \\
\hline Workspace & & Labor & & Rework & \\
\hline $\begin{array}{l}\text { Storage: stock of } \\
\text { materials or } \\
\text { components }\end{array}$ & & $\begin{array}{l}\text { Equipment / } \\
\text { Tools }\end{array}$ & & Material wastes & \\
\hline Equipment / tools & & Space & & $\begin{array}{l}\text { Compromises } \\
\text { security }\end{array}$ & \\
\hline $\begin{array}{l}\text { Provisional installation: } \\
\text { water and electricity } \\
\text { supply }\end{array}$ & & $\begin{array}{l}\text { Interconnected } \\
\text { Services }\end{array}$ & & Demotivation & \\
\hline Protection & & $\begin{array}{c}\text { External } \\
\text { Conditions }\end{array}$ & & \multirow[b]{2}{*}{ Lack of terminality } & \multirow{2}{*}{$\begin{array}{c}\text { Fireman } \\
(2012)\end{array}$} \\
\hline Sequencing & $\begin{array}{l}\text { Fireman } \\
(2012)\end{array}$ & $\begin{array}{c}\text { Facilities: } \\
\text { workspace } \\
\text { infrastructure }\end{array}$ & $\begin{array}{l}\text { Sommer } \\
(2010)\end{array}$ & & \\
\hline
\end{tabular}

Source: Santos \& Santos (2017).

\section{Risk management in civil construction}

Risk management is an area of study and performance whose main objective is to analyze projects, companies and other organizations within its context to identify uncertain future events that may influence the studied entity's goal achievement (Figueiredo \& Catarina, 2016).

According to Santa Catarina (2008), the main risk management activities and stages can be divided into: a) Formal definition of a risk management plan; b) Identification and registration of risks; c) Qualification, quantification and hierarchy; d) Definition of risk treatment actions; e) Monitoring of treatment actions and f) Monitoring framework.

For the author, when the objective is only to know the risks, risk management can be simplified by applying only steps $b$ and c. Qualification is, therefore, a later and important phase in the analysis.

According to Fireman (2012), the analysis considers the severity of the case and its probability of repetition. The method proposed by the author is based on a subjective and qualitative assessment of the cases and allows them to be divided into three groups: high priority (black), medium priority (gray) and low priority (light gray) (Table 2). 
Table 2. Risk analysis.

\begin{tabular}{cccccc}
\hline \multirow{2}{*}{ PROBABILITY } & \multicolumn{5}{c}{ SEVERITY } \\
\cline { 2 - 6 } & Very High- I & High - II & Moderate - III & Low - IV & Very Low- V \\
\hline A - Improbable & DG & DG & LG & LG & LG \\
\hline B - Extremely Remote & DG & DG & DG & LG & LG \\
\hline C - Remote & B & DG & DG & DG & LG \\
\hline D - Probable & B & B & DG & DG & DG \\
\hline E - Frequent & B & B & B & DG & DG \\
\hline
\end{tabular}

Subtitle: DG: dark grey, LG: light gray, B: black. Source: Adapted from Fireman (2012).

\section{Method}

\subsection{Search ranking}

This work is classified as mixed methods research, that is, it combines qualitative and quantitative research approach. According to Santos \& Santos (2017), the use of mixed method research is indicated when the results of an approach can be better interpreted with a second data source, that is, when the qualitative or quantitative approach alone is not enough to understand the problem to be studied.

This research is characterized as quantitative, as it proposes to carry out a collection of related data on making-doin different construction companies and construction sites and to analyze them according to their percentage values presented in categories, prerequisites and impacts.

Qualitative research, in turn, is associated with the acquisition of descriptive data associated with people, places and processes through direct contact between the researcher and the situation to be studied (Godoy, 1995). This work is characterized as qualitative research insofar as it proposes to analyze the causes of wastes due to makingdo and its interrelationships by regions, processes and execution particularities.

\subsection{Data collection and analysis}

The determining criteria for the selection of the companies participating in the research were: a) Interest in participating in academic studies aimed at improving their processes and reducing wastes through making-do; b) Having a Quality Management System or mapped and monitored processes, allowing access to information such as: planning and follow-up, verification sheets and services, checklists, among others; c) Present undertakings in execution that make it possible to collect data for research.

For the identification and classification of loss by making-do, we used the method proposed by Formoso et al. (2011) and then complemented by Fireman (2012), divided into three groups: identifying the wastes by making-do, assessing the impact of the identified wastes and identifying the necessary prerequisites or preconditions for working conditions.

From the definition of the participating companies, they were characterized, as shown in Table 3. 
Table 3. Characterization of participating companies.

\begin{tabular}{|c|c|c|c|c|c|}
\hline Company & Certifications & $\begin{array}{c}\text { Time in } \\
\text { the } \\
\text { market }\end{array}$ & $\begin{array}{l}\text { Works in progress in the } \\
\text { second half of } 2018\end{array}$ & $\begin{array}{c}\mathrm{m}^{2} \text { under } \\
\text { construction in } \\
2018\end{array}$ & $\begin{array}{l}\text { Company } \\
\text { size }\end{array}$ \\
\hline \multirow{4}{*}{ A } & \multirow{4}{*}{ No certifications } & \multirow{4}{*}{12 years } & $\begin{array}{l}\text { Two floors residential house } \\
\text { Renovation (High standard) }\end{array}$ & 260.00 & \multirow{4}{*}{ Midsize } \\
\hline & & & $\begin{array}{l}\text { Residential House (High } \\
\text { standard) }\end{array}$ & 432.00 & \\
\hline & & & 3 Industrial Works & 801.00 & \\
\hline & & & $\begin{array}{c}\text { Automotive Vehicle } \\
\text { Concession Reform - Rio } \\
\text { Verde - GO }\end{array}$ & 615.00 & \\
\hline \multirow{2}{*}{ B } & \multirow{2}{*}{ PBQPH-A } & \multirow{2}{*}{37 years } & $\begin{array}{l}\text { Residential Building (High } \\
\text { standard) }\end{array}$ & 30836.06 & \multirow{2}{*}{ Large } \\
\hline & & & $\begin{array}{l}\text { Residential Building (High } \\
\text { standard) }\end{array}$ & 31128.20 & \\
\hline \multirow{2}{*}{$\mathrm{C}$} & \multirow{2}{*}{ ISO 9001} & \multirow{2}{*}{26 years } & $\begin{array}{l}\text { Residential Building (High } \\
\text { standard) }\end{array}$ & 31621.96 & \multirow{2}{*}{ Large } \\
\hline & & & $\begin{array}{l}\text { Residential Building (High } \\
\text { standard) }\end{array}$ & 30233.45 & \\
\hline \multirow{4}{*}{$\mathrm{D}$} & $\begin{array}{l}\text { ABNT NBR ISO } \\
14001\end{array}$ & \multirow{4}{*}{21 years } & $\begin{array}{l}\text { Residential building (Medium } \\
\text { standard) }\end{array}$ & 47789.71 & \multirow{4}{*}{ Large } \\
\hline & ISO 9001 & & College & 11063.00 & \\
\hline & OHSAS 18001 & & \multirow{2}{*}{$\begin{array}{l}03 \text { EHI's (01 in Goiânia and } \\
02 \text { in Rio de Janeiro) }\end{array}$} & $12493.00 \mathrm{GO}$ & \\
\hline & PBQPH- level A & & & $\begin{array}{l}\text { 12595.01 RJ } \\
26001.22 \mathrm{RJ}\end{array}$ & \\
\hline \multirow{4}{*}{$E$} & \multirow[t]{2}{*}{ ISO 9001} & \multirow{4}{*}{19 years } & $\begin{array}{l}\text { Residential building (Medium } \\
\text { standard) }\end{array}$ & 20853.13 & \multirow{4}{*}{ Large } \\
\hline & & & 02 Residential buildings (High & 23219.83 & \\
\hline & \multirow{2}{*}{ PBQPH- level A } & & standard) & 24796.84 & \\
\hline & & & Hotel / residential building & 19572.45 & \\
\hline \multirow{2}{*}{$\mathrm{F}$} & \multirow{2}{*}{ ISO 9001} & \multirow{2}{*}{32 years } & \multirow{2}{*}{$\begin{array}{l}02 \text { Residential buildings } \\
\text { (Medium standard) }\end{array}$} & 27169.88 & \multirow{2}{*}{ Large } \\
\hline & & & & 29279.84 & \\
\hline \multirow{2}{*}{ G } & \multirow[t]{2}{*}{ ISO 9001} & \multirow{2}{*}{21 years } & $\begin{array}{l}\text { Residential building (High } \\
\text { standard) }\end{array}$ & 31698.24 & \multirow{2}{*}{ Large } \\
\hline & & & $\begin{array}{l}\text { Residential building (Medium } \\
\text { standard) }\end{array}$ & 64171.75 & \\
\hline
\end{tabular}

Source: Own authorship (2018).

The data were collected from seven construction companies in the city of Goiânia between the months of July 2017 and August 2018. The data collection required for the survey took place in all the enterprises of the companies participating in the survey.

The questionnaires were applied in a semi-structured manner to the engineers, masters of construction and those in charge at the construction sites to obtain better details and associations of the surveyed records.

In this work, direct observations and field notes were essential to evidence the data. Direct observations were made during field visits, and the notes taken were intended to explain the occurrence in detail of the work development, which were associated with photos to record the activities performed.

Photographic records and document analyses were performed to prove the facts and correct classification of wastes. The images increased the communication power of the information, besides constituting an important record of the characteristics of the study of multi-cases.

For each work visited, we sought to analyze the following documents: schedule, short and medium term planning and service verification sheets. The set of these documents 
served as a basis for data processing. At the same time, we sought to prove the qualifications of the companies.

The data collected were organized with the aid of Excel software in a spreadsheet for further analysis and data processing (Figure 2). The definitions presented in Table 4 were used to fill the spreadsheet. From the database, the dynamic spreadsheet (Dashboard) was created in order to enable the analysis and processing of data in a global analysis (Figure 3). With the Dashboard it was possible to associate the data, promoting a more dynamic interface, making it possible to obtain different analyses automatically.

\begin{tabular}{|c|c|c|c|c|c|c|c|c|c|c|c|}
\hline COMPANY & STEP & SUBETAPE & $\begin{array}{c}\text { PRE- } \\
\text { REQUTREMENTS }\end{array}$ & DESCRIPTION & CAUSE & MAGE & теАм & CATEGORY & IMPACTS & $\begin{array}{l}\text { OTHER } \\
\text { LOSSES }\end{array}$ & DATE \\
\hline & & & & & & & & & & & \\
\hline
\end{tabular}

Figure 2. Database model. Source: Own authorship (2018).

Table 4. Worksheet for classification of wastes by making-do.

\begin{tabular}{cccc}
\hline PRE CONDITIONS & CATEGORIES & IMPACTS & OTHER WASTES \\
\hline $\begin{array}{c}\text { Information } \\
\text { components }\end{array}$ & Access / Mobility & Decreased productivity & Replacement \\
\hline Labor & Womponent adjustment & Demotivation & Overproduction \\
\hline $\begin{array}{c}\text { Equipment and Tools } \\
\text { Space }\end{array}$ & Equipment / Tools & Reduced security & Defective product \\
\hline $\begin{array}{c}\text { Interdependent } \\
\text { services }\end{array}$ & Temporary installations & Quality reduction & \\
\hline External conditions & Protection & Lack of terminality & \\
\hline Installations & Sequencing & Cost & \\
\hline & & Schedule & \\
\hline
\end{tabular}

Source: Own authorship (2018).

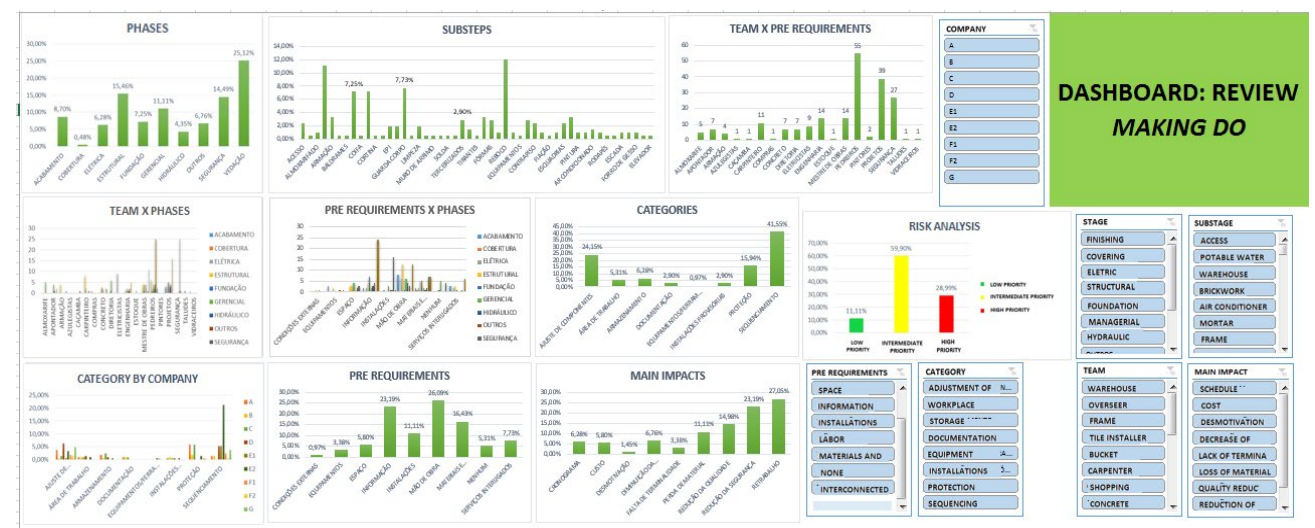

Figure 3. Dashboard template. Source: Own authorship (2018).

This analysis is done in three stages: construction of the database as a matrix (1), assembly of dynamic tables by means of a specific command of the Excel software (2) followed by construction of dynamic graphs (3). Through its own algorithm and selection of multifilters, the software crosses the information contained in the database generating 
percentages. These in turn are interpreted graphically from the selected filters, generating numerous interpretations.

At the end, risk analysis was performed according to parameters defined by Fireman (2012), presented in Table 2.

The severity criteria "Very High" and "High" were chosen for cases that affected the safety of employees, significantly impacted the project's budget and schedule and required quick decisions by the management team due to their impacts.

The "Moderate" criterion was defined for failures that did not require immediate decisions or that affected the project's schedule and budget to a lesser extent.

The "Low" and "Very Low" criteria were assigned to events with quick and easy resolution and low impacts on the project's schedule and budget.

The probability criterion was defined according to the number of occurrences of failures registered in the studied projects and in the researchers' previous experiences in construction sites. High-incidence cases were defined as frequent, low-frequency cases as probable, and cases with small occurrences were distributed as improbable, extremely remote and remote according to the criteria set out above.

As a result of crossing these criteria (severity and probability), the level of priority of the failures collected was obtained, namely: high priority, medium priority and low priority.

With the definition of the priority classification of each case, we proceeded with the calculation of the order of priority for each category. This calculation was made by the relationship between the number of cases in each category, for each priority classification, and the total number of cases in each category.

\section{Results}

Each work visited was characterized, which is shown in Table 5. It is noteworthy that two undertakings from companies " $E$ " and "F" were followed.

Table 5. Characterization of the works. Source: Own authorship (2018)

\begin{tabular}{|c|c|c|c|c|c|c|c|c|}
\hline \multicolumn{9}{|c|}{ CHARACTERIZATION OF WORKS } \\
\hline 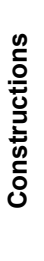 & 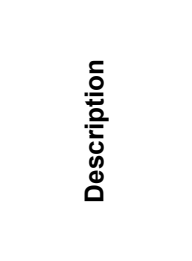 & 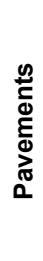 & 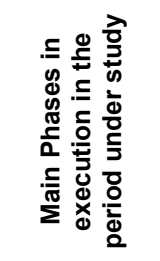 & 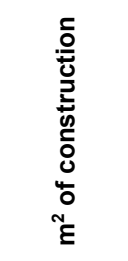 & 高 & 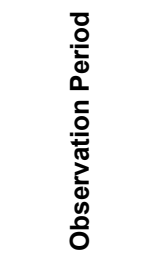 & 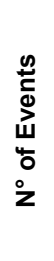 & 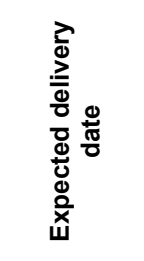 \\
\hline \multirow{5}{*}{ A } & \multirow{5}{*}{$\begin{array}{l}\text { High Standard } \\
\text { Single Family } \\
\text { Residential } \\
\text { Development }\end{array}$} & \multirow{5}{*}{3} & Foundation & \multirow{5}{*}{432.00} & \multirow{5}{*}{$\begin{array}{l}\text { Outsourced } \\
\text { and Own }\end{array}$} & \multirow{5}{*}{$\begin{array}{l}5 \text { months of } \\
\text { observation }\end{array}$} & \multirow{5}{*}{30} & \multirow{5}{*}{$30 / 11 / 2018$} \\
\hline & & & Structure & & & & & \\
\hline & & & Masonry & & & & & \\
\hline & & & Installations & & & & & \\
\hline & & & Plastering & & & & & \\
\hline \multirow{4}{*}{ B } & \multirow{4}{*}{$\begin{array}{l}\text { High Standard } \\
\text { Residential } \\
\text { Building }\end{array}$} & \multirow{4}{*}{34} & Structure & \multirow{4}{*}{30836.06} & \multirow{4}{*}{$\begin{array}{l}\text { Outsourced } \\
\text { and Own }\end{array}$} & \multirow{4}{*}{2 visits } & \multirow{4}{*}{13} & \multirow{4}{*}{$03 / 2020$} \\
\hline & & & Masonry & & & & & \\
\hline & & & Installations & & & & & \\
\hline & & & Plastering & & & & & \\
\hline \multirow{4}{*}{ C } & \multirow{4}{*}{$\begin{array}{l}\text { High Standard } \\
\text { Residential } \\
\text { Building }\end{array}$} & \multirow{4}{*}{36} & Foundation & \multirow{4}{*}{31621.96} & \multirow{4}{*}{$\begin{array}{l}\text { Outsourced } \\
\text { and Own }\end{array}$} & \multirow{4}{*}{2 visits } & \multirow{4}{*}{23} & \multirow{4}{*}{$11 / 2020$} \\
\hline & & & Structure & & & & & \\
\hline & & & Masonry & & & & & \\
\hline & & & Installations & & & & & \\
\hline
\end{tabular}


Table 5. Continued...

\begin{tabular}{|c|c|c|c|c|c|c|c|c|}
\hline \multicolumn{9}{|c|}{ CHARACTERIZATION OF WORKS } \\
\hline \multirow{5}{*}{$\mathrm{D}$} & \multirow{5}{*}{$\begin{array}{l}\text { High Standard } \\
\text { Residential } \\
\text { Building }\end{array}$} & \multirow{5}{*}{37} & Plastering & \multirow{5}{*}{47789.71} & \multirow{5}{*}{$\begin{array}{l}\text { Outsourced } \\
\text { and Own }\end{array}$} & \multirow{2}{*}{3 visits } & \multirow{5}{*}{30} & \multirow{2}{*}{$\begin{array}{l}\text { Tower A } \\
05 / 2019\end{array}$} \\
\hline & & & Masonry & & & & & \\
\hline & & & Installations & & & & & \\
\hline & & & Frames & & & 3 visits & & $\begin{array}{l}\text { lower B } \\
10 / 2018\end{array}$ \\
\hline & & & Finishes & & & & & \\
\hline \multirow{5}{*}{ E1 } & \multirow{5}{*}{$\begin{array}{l}\text { Medium Standard } \\
\text { Residential } \\
\text { Building }\end{array}$} & \multirow{5}{*}{31} & Structure & \multirow{5}{*}{20853.13} & \multirow{5}{*}{$\begin{array}{l}\text { Outsourced } \\
\text { and Own }\end{array}$} & \multirow{5}{*}{4 visits } & \multirow{5}{*}{12} & \multirow{5}{*}{$10 / 2018$} \\
\hline & & & Masonry & & & & & \\
\hline & & & Installations & & & & & \\
\hline & & & Frames & & & & & \\
\hline & & & Finishes & & & & & \\
\hline \multirow{5}{*}{ E2 } & \multirow{5}{*}{$\begin{array}{l}\text { Medium Standard } \\
\text { Residential } \\
\text { Building }\end{array}$} & \multirow{5}{*}{31} & Structure & \multirow{5}{*}{20853.13} & \multirow{5}{*}{$\begin{array}{l}\text { Outsourced } \\
\text { and Own }\end{array}$} & \multirow{5}{*}{6 visits } & \multirow{5}{*}{59} & \multirow{5}{*}{$10 / 2018$} \\
\hline & & & Masonry & & & & & \\
\hline & & & Installations & & & & & \\
\hline & & & Frames & & & & & \\
\hline & & & Finishes & & & & & \\
\hline \multirow{5}{*}{$\mathrm{F} 1$} & \multirow{5}{*}{$\begin{array}{l}\text { High Standard } \\
\text { Residential } \\
\text { Building }\end{array}$} & \multirow{5}{*}{34} & Structure & \multirow{5}{*}{27169.88} & \multirow{5}{*}{$\begin{array}{l}\text { Outsourced } \\
\text { and Own }\end{array}$} & \multirow{5}{*}{2 visits } & & \\
\hline & & & Masonry & & & & & \\
\hline & & & Installations & & & & 11 & $10 / 2019$ \\
\hline & & & Frames & & & & & \\
\hline & & & Finishes & & & & & \\
\hline & High Standard & & Foundation & & & & & \\
\hline $\mathrm{F} 2$ & Residential & 27 & & 29279.84 & $\begin{array}{l}\text { Outsourced } \\
\text { and Own }\end{array}$ & 4 visits & 5 & $12 / 2020$ \\
\hline & Building & & Structure & & & & & \\
\hline & & & Structure & & & & & \\
\hline G & $\begin{array}{l}\text { High Standard } \\
\text { Residential } \\
\text { Building }\end{array}$ & 41 & Masonry & 31698.24 & $\begin{array}{l}\text { Outsourced } \\
\text { and Own }\end{array}$ & 2 visits & 18 & $04 / 2020$ \\
\hline & & & Installations & & & & & \\
\hline
\end{tabular}

The enterprise of company "A" was used as a pilot for the creation of the Dashboard, due to the possibility of greater monitoring of the records, this tool was continuously improved to obtain greater interaction between the data and meeting the research objectives.

\subsection{Creation of a new category}

From the monitoring of the nine projects, 207 occurrences were recorded for making-do.

In work "A", in which the research was monitored for a longer period, it was possible to verify the following contractual failure: start of outsourced activities without the presentation of all necessary labor and safety documentation.

Rescuing the concept presented by Koskela (2004), loss by making-do is established when a task starts without all its inputs, necessary resources, or when it has its continued execution, even with the assignment of one or more entries. Based on this concept, we sought to verify in other works whether this contractual failure was frequent, which would justify the creation of a new category of loss by making-do.

For this, the types of documentation that make up this new category were defined. Labor documentation (contractor's contract, contract between contractor and contractor, copy of municipal permit, employee life insurance, negative FGTS and social security 
certificates, union contribution and CNPJ (General Taxpayer's Registry) card, copies of RG, CPF, PIS (Brazilian identity) card) were included in this category, work card, employment contract and employee record sheet) and security (Environmental risk prevention program, Occupational health medical control program, personal protective equipment sheets, work order and copies of health certificates occupational health).

Also included in this category are documents related to machinery and environment operations required for specific services, such as a portfolio of the Brazilian Institute for the Environment and Renewable Natural Resources (IBAMA), specific function training and others.

\subsection{Main records and graphic analysis}

Of the occurrences of making-do recorded in the studied constructions, the "Sequencing" category stands out, with $41.55 \%$ of registered cases (Figure 4 ).

Sommer (2010) found in his work a value of $56 \%$ for the same category whereas Leão et al. (2016) found values of $31 \%$ for sequencing and $13 \%$ for the storage category.

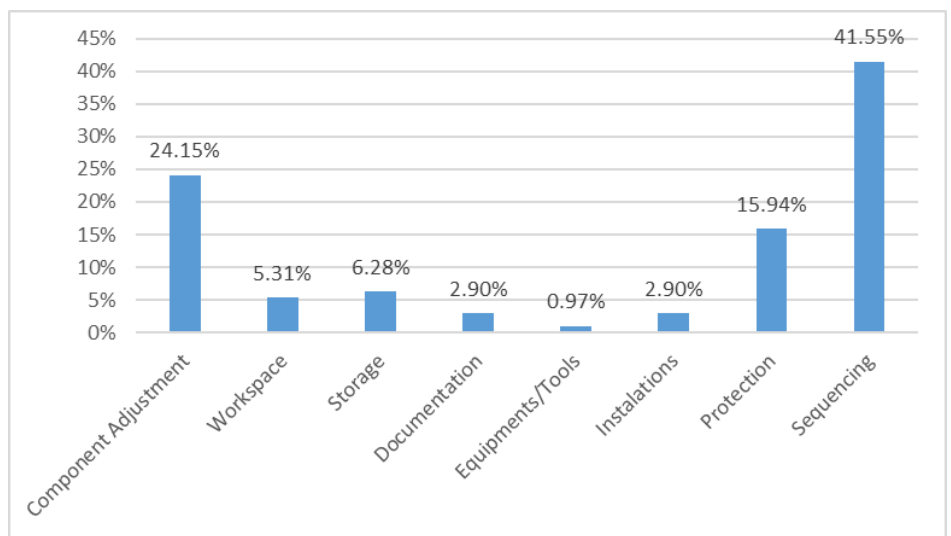

Figure 4. Survey of wastes by making-do classified by categories. Source: Own authorship (2018).

The values found are considered high, since these companies have a Quality Management System (QMS) implemented and their processes are standardized and monitored. It is highlighted that only company A has no certification. Evaluating the processes related to sequencing, there is a greater number of failures in the substep "Masonry" (Figure 5).

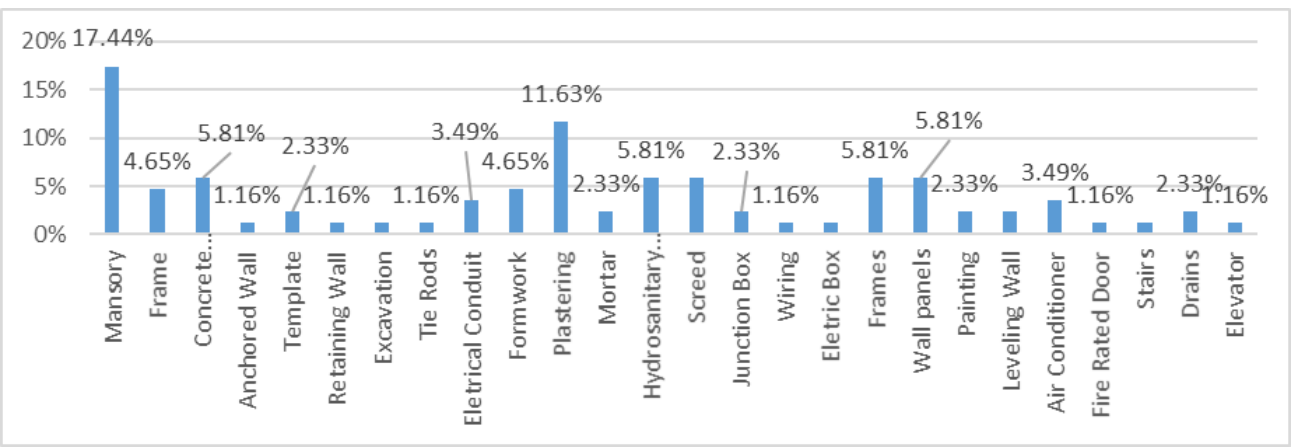

Figure 5. Substeps by category. Source: Own authorship (2018). 
According to the analyzes carried out, this question had a higher incidence due to changes in personalized apartments, which were sometimes sent to the construction site late, causing changes in the masonry that had already been executed. This is in line with the conclusions of Brandão \& Elias (2018), with emphasis on the impacts on the schedule, cost, material loss and rework.

Regarding the missing prerequisites, "labor" stood out with $26.09 \%$ of the total cases, followed by "information" with $23.19 \%$ of the cases (Figure 6). Brandão \& Elias (2018) found in their research similar values of $20.9 \%$ for "labor" and the prerequisite information $(27.3 \%)$ as one of the main origins of improvisations. In the work of Leão et al. (2016) in relation to the nature of wastes from making-do, the values of $43 \%$ for equipment / tools and $39 \%$ for interconnected services were found.

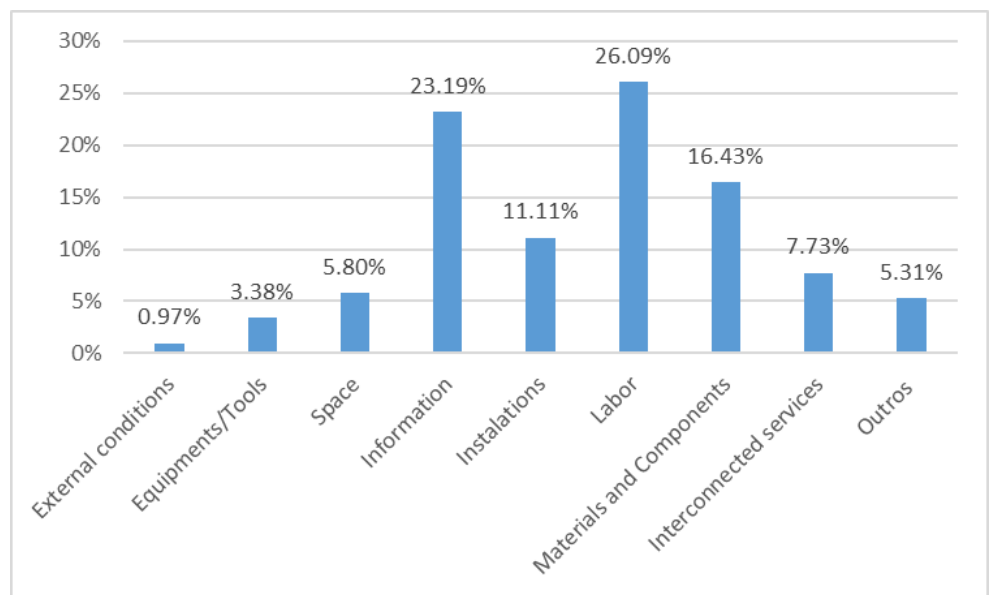

Figure 6. Percentage of prerequisites. Source: Own authorship (2018).

This analysis is in line with the results obtained in relation to the sequencing category, demonstrating that recurrent failures in the transmission of information (changes in customized apartments, for example) directly influence failures during masonry execution.

When analyzing the main impacts of wastes due to making-do, rework was confirmed with $27.05 \%$ of the main impacts generated, followed by the reduction of security with $23.19 \%$ of the analyzed data (Figure 7 ).

In the work of Leão et al. (2016), the values of $38 \%$ for lack of terminality and $24 \%$ for decreased productivity were found. It is worth mentioning that the integration between production and quality controls is a means of reducing the incidence of informal packages and, consequently, wastes due to making-do.

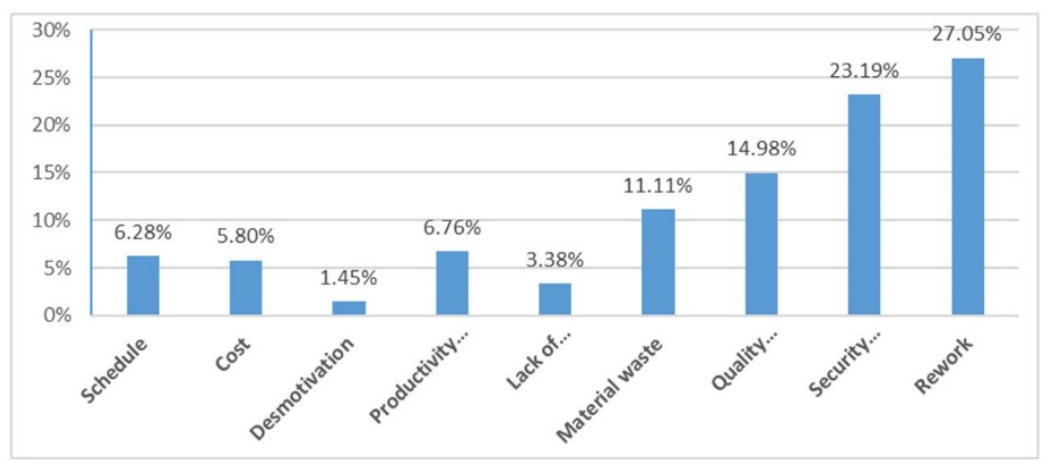

Figure 7. Main impacts. Source: Own authorship (2018). 
It was noticed through the analysis of the records that the high rate of rework is directly linked to the ineffective control between the activities present in the work, control of projects and their changes and control of execution and conformities. The failures of control and inspection of the various sequential processes were the main reasons found to justify this high rate, recorded in practically all stages and substeps followed in the works.

The high rate of safety reduction is due to the inappropriate use of materials, failures in the use of Personal Protective Equipment and the absence or non-conformity of Collective Protection Equipment.

\subsection{Risk analysis}

From the records made, it was possible to perform risk analysis of each occurrence. The occurrences by making-do were classified according to their severity and their probability of occurrence (Table 2).

With the help of engineers, masters and supervisors, it was possible to confirm the incidence of the records made and to classify each record according to its probability of occurrence (from unlikely to frequent). Through experience and discussions with the executors of the works, the records were also classified according to their severity (from very high to very low). From this correlation, the records were classified according to the need for intervention in low, medium and high priority.

Of the 207 cases per making-do recorded, about $29 \%$ were classified as high priority, followed by $60 \%$ as medium priority, and $11 \%$ as low priority.

Of the steps recorded in the survey, "Safety" was the one with the highest number of occurrences that lack a high priority for intervention, with around $83.33 \%$ of cases (Figure 8).

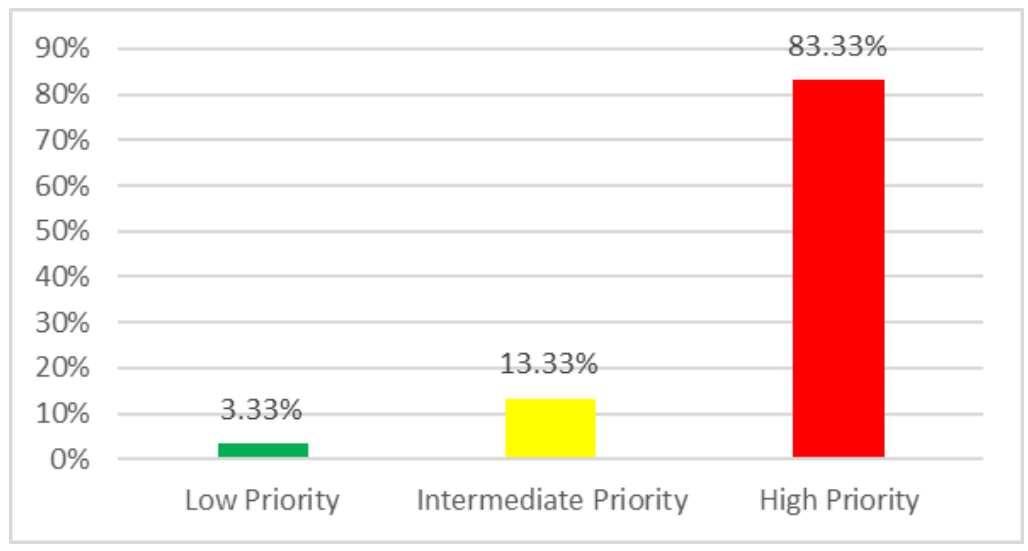

Figure 8. Risk analysis of the security category. Source: Own authorship (2018).

The analysis regarding the relationship between missing prerequisites and the need for intervention is pertinent. From the records made, those linked to "Facilities" had a greater need for interventions, presenting about $65.22 \%$ of these cases (Figure 9). 


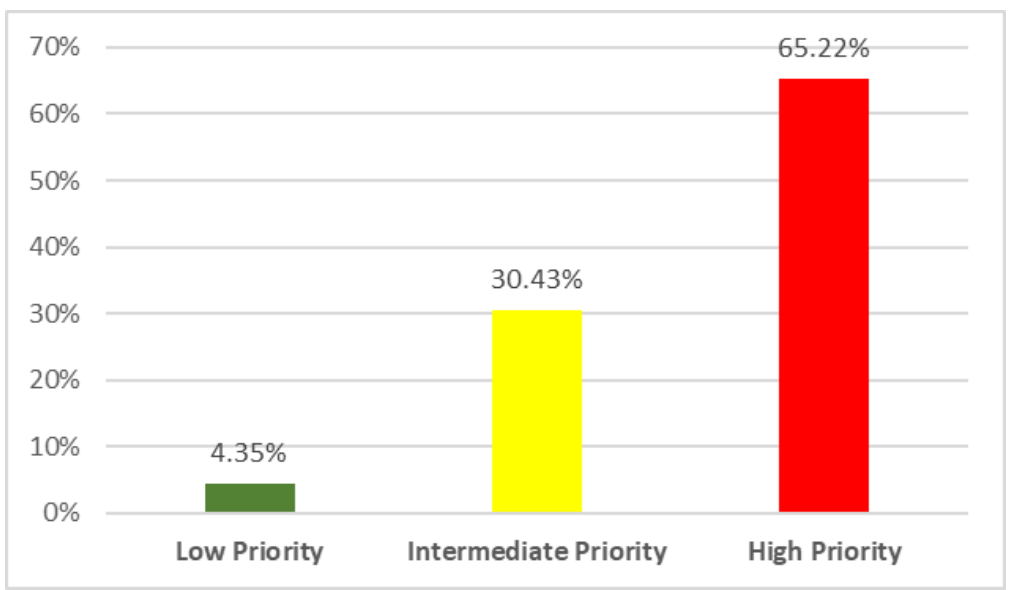

Figure 9. Risk analysis of the prerequisite facilities. Source: Own authorship (2018).

\section{Conclusions}

The objective of proposing a dynamic method to identify and analyze wastes from making-do in construction sites was met.

From the results obtained, it is worth emphasizing the importance of studying wastes related to making-do, using the dynamic tables. The dynamics of the results obtained, using this tool, provides a systemic analysis of the various factors involved in the records collected, serving as a basis for management decision making. At the same time it can be used as a tool to control the activities of related works and documentation, being used as a diagnosis of execution problems.

Effective control of activities and execution of structured action plans are effective measures to minimize the occurrences of making-do. These actions must be programmed and improved periodically, since the execution of the work is also multifaceted. As with activities, inspection agents inside and outside construction sites must be monitored and constantly trained to do so, so that the process of continuous improvement within works involves the entire hierarchy of the construction process, from the operational to the strategic level.

We highlight the convergences between the previous works of Brandão \& Elias (2018) and Braga (2018), Sommer (2010), Leão et al. (2016), in which sequencing was the category with the highest incidence, followed by different categories in the referenced works.

Rework and safety reduction were the main impacts of the survey, in conjunction with the results obtained by Sommer (2010), Brandão \& Elias (2018) and Braga (2018). We also highlight security reduction as the impact with greater risk and need for interventions.

This research was able to raise a significant sample of data related to wastes due to making-do in Goiânia. It is noteworthy that the situations of records, processes and particularities of each work influence the data collected. As a result of these factors, we recommend expandinf the sample collected to other States and analyzing them by constructive process and typology.

From the conclusions presented, it is suggested for future work:

Use augmented reality to view the procedures for executing services, helping to identify wastes from making-do;

Develop information technology tools that assist in data collection at construction sites, for the integrated control of production and the incidence of wastes from making-do. 


\section{References}

Adewuyi, T. O., Idoro, G. I., \& Ikpo, I. J. (2014). Empirical evaluation of construction material waste generated on sites in Nigeria. Civil Engineering Dimension, 16(2), 96-103. http://dx.doi.org/10.9744/ced.16.2.96-103.

Alves, T. (2000). Diretrizes para gestão de fluxos físicos em canteiros de obras: proposta baseada em estudos de caso (Dissertação de mestrado). Universidade Federal do Rio Grande do Sul, Porto Alegre.

Ansah, R. H., Sorooshian, S., \& Mustafa, S. B. (2016). Lean construction: an effective approach for project management. Arpn Journal of Engineering and Applied Sciences, 11(3), 1607-1612.

Ballard, G. (2000). The last planner system of production control (Thesis Ph.D). School of Civil Engineering, Faculty of Engineering, University of Birmingham, Birmingham.

Barbosa, G., Andrade, F., Biotto, C., \& Mota, B. (2013). Implementing Lean Construction effectively in a year in a construction project. In Proceedings of the 21st Annual Conference of the International Group for Lean Construction. USA: International Group for Lean Construction.

Bonesi, F. M. (2014). Avaliação do impacto provocado pelos processos construtivos racionalizados nas perdas por making-do (Trabalho de Conclusão de Curso). Universidade Federal do Rio Grande do Sul, Porto Alegre.

Braga, P. B. (2018). Análise de perdas por make-do por meio de planilhas dinâmicas (Trabalho de Conclusão de Curso). Universidade Federal de Goiás, Goiânia.

Brandão, C. M., \& Elias, K. V. (2018). Identification of improvisation wastes in construction sites (Trabalho de Conclusão de Curso). Universidade Federal de Goiás, Goiânia.

Dinoah, L. O., Martins, A. G., \& Ribeiro, R. G. O. S. (2018). Determination of wastes from making-do in companies in Goiás (Trabalho de Conclusão de Curso). Universidade Federal de Goiás, Goiânia.

Figueiredo, G. S., \& Catarina, A. S. (2016). Risk analysis: identification and description of risks in the development of a real estate project from the perspective of a non-manager investor. Iberoamericana Magazine of Industrial Engineering, 8(15), 1-16.

Fireman, M. C. T. (2012). Proposta de método de controle integrado entre produção e qualidade com mensuração de perdas por making-do e pacotes informais (Dissertação de mestrado). Universidade Federal do Rio Grande do Sul, Porto Alegre.

Fireman, M. C. T., Formoso, C. T., \& Isatto, E. L. (2013). Integrating productionand quality control: monitoring making-do and unfinished work. In Proceedings of the 21st Annual Conference of the International Group for Lean Construction. USA: International Group for Lean Construction.

Formoso, C. T., \& Moura, C. B. (2009). Evaluation of the impact of the last planner system on the performance of construction projects. In Annual Conference of the 17th International Group for Lean Construction. USA: International Group for Lean Construction.

Formoso, C. T., Cesare, C. M., Lantelme, E. M. V., \& Soibelman, L. (1997). As perdas na construção civil: conceitos, classificações e seu papel na melhoria do setor (pp. 1-11). Porto Alegre: UFRGS/NORIE.

Formoso, C. T. (1998). As perdas na construção civil: conceitos, classificações e seu papel na melhoria do setor. Porto Alegre: UFRGS/NORIE.

Formoso, C. T., Soibelman, L., De Cesare, C., \& Isatto, E. L. (2002). Material Waste in Building Industry: main causes and prevention. Journal of Construction Engineering and Management, 128(4), 316-325. http://dx.doi.org/10.1061/(ASCE)0733-9364(2002)128:4(316).

Formoso, C. T., Sommer, L., Koskela, L. J., \& Isatto, E. L. (2011). An exploratory study on the measurement and analysis of making-do in construction sites. In Proceedings of the 19st Annual Conference of the International Group for Lean Construction. USA: International Group for Lean Construction.

Formoso, C. T., Sommer, L., Koskela, L., \& Isatto, E. L. (2017). The identification and analysis of making-do waste: insights from two Brazilian construction sites. Ambiente Construído, 17(3), 183-197. http://dx.doi.org/10.1590/s1678-86212017000300170. 
Godoy, A. S. (1995). Qualitative research and its use in Business Administration. Revista de Administração de Empresas, 35(4), 65-71. Retrieved in 2019, August 29, from https://www.scielo.br/j/rae/a/NkTFNgmLWKXfT6k9P9qBTMn/?lang=pt

Hwang, B., Thomas, S. R., Haas, C. T., \& Caldas, C. H. (2009). Measuring the impact of rework on construction cost performance. Journal of Construction Engineering and Management, 135(3), 187-198. http://dx.doi.org/10.1061/(ASCE)0733-9364(2009)135:3(187).

Koskela, L. (1992). Application of the new production philosophy to construction (Technical Report, No 72). Stanford: Center for Integrated Facility Engineering, Stanford University.

Koskela, L. (1999). Management of production in construction: a theoretical view. In Proceedings of the 7st Annual Conference of the International Group for Lean Construction. USA: International Group for Lean Construction.

Koskela, L. (2000). An exploration into a theory of production and its application to construction (VTT Publication, No. 408). Finland: VTT Building Technology. Retrieved in 2019, August 29, from http://urn.fi/urn:nbn:fi:tkk-001187

Koskela, L. (2004). Making-do - the eighth category of waste. In Proceedings of the 12th Annual Conference of the International Group for Lean Construction. USA: International Group for Lean Construction.

Koushki, P. A., \& Kartam, N. (2004). Impact of construction materials on project time and cost in Kuwait. Engineering, Construction, and Architectural Management, 11(2), 126-132. http://dx.doi.org/10.1108/09699980410527867.

Leão, C. F. (2014). Proposta de modelo de produção integrada e controle de qualidade utilizando tecnologia da informação (Dissertação de mestrado). Universidade Federal do Rio Grande do Sul, Porto Alegre.

Leão, C. F., Isatto, E. L., \& Formoso, C. T. (2016). Proposed model for integrated production and quality control with the support of mobile computing. Built Environment, Porto Alegre, 16(4), 109-124.

Love, P. L. H., \& Li, H. (2000). Quantifying the causes and costs of rework in construction. Construction Management and Economics, 18(4), 479-490. http://dx.doi.org/10.1080/01446190050024897.

Machado, R. L. (2003). A sistematização de antecipações gerenciais no planejamento da produção de sistemas da construção civil (Tese de doutorado). Universidade Federal de Santa Catarina, Florianópolis.

Ohno, T. (1988). Toyota production system: beyond large-scale production. Cambridge, Massachusetts: Productivity Press.

Ohno, T. (1997). Toyota production system - in addition to large scale production. Porto Alegre: Bookman Publisher.

Ronen, B. (1992). The complete kit concept. International Journal of Production Research, 30(10), 57-66. http://dx.doi.org/10.1080/00207549208948166.

Santa Catarina, A. (2008). Análise de riscos em projetos de infra-estrutura: modelando a interface entre o gerenciamento de riscos de investidores e gestores em dois projetos do setor elétrico brasileiro (Tese de doutorado). Universidade Federal de Santa Catarina, Florianópolis.

Santos, D. G. (2004). Modelo de gestão de processos na construção civil para identificação de atividades facilitadoras (Tese de doutorado). Universidade Federal de Santa Catarina, Florianópolis.

Santos, P. R. R., \& Santos, D. G. (2017). Investigation of wastes due to unfinished work and its impact on the cycle time of construction processes. Built Environment, 17(2), 39-52.

Shingo, S. (1989). A study of the Toyota Production System - from an industrial engineering viewpoint. Portland: Productivity Press.

Silva, R. C. M. (2013). Avaliação das perdas por improvisação no processo de produção em canteiros de obras: estudo de caso na cidade de Maceió/AL (Trabalho de Conclusão de Curso). Universidade Federal de Alagoas, Maceió. 
Sommer, L. (2010). Contribuições para um método de identificação de perdas por improvisação em canteiros de obras (Dissertação de mestrado). Universidade Federal do Rio Grande do Sul, Porto Alegre.

Soibelman, L. (1993). As perdas de materiais na construção de edificações: sua incidência e controle (Dissertação de mestrado). Universidade Federal do Rio Grande do Sul, Porto Alegre.

Veloso, C. O. (2014). Perdas por improvisação em obra e sua relação com o planejamento de médio prazo (Trabalho de Conclusão de Curso). Universidade Federal da Bahia, Salvador.

Viana, D. D., Formoso, C. F., \& Kalsaas, B. T. (2012). Waste in construction: a systematic literature review on empirical studies. In Proceedings of the 20th Annual Conference of the International Group for Lean Construction. San Diego, California: Montezume Publishing. 